\title{
EVIDENCE OF SNOW-PLUNGING BY BOREAL AND BARRED OWLS
}

ROBERT W. NERO, Box 14, 1495 St. James Street, Winnipeg, Manitoba, R3H OW9

In 1978, Curry-Lindahl, in his foreward to a major reference on technical publications about owls, noted that "...many species of owls rely not only on a sensitive vision, but, if necessary, to a considerable extent also on remarkable auditory powers when hunting rodents and shrews during the winter when these mammals often move under the snow cover. At least the tawny owl, Short-eared Owl (Asio flammeus) and Long-eared Owl ( $A$. otus) are able to localize from the air, invisible small mammals and to catch them 'blindly' on the right spot below the snow surface. Probably also other species of owls use this technique; I am almost certain that the Boreal (Tengmalm's) owl (Aegolius funereus) does it."

Snow-plunging as a method of obtaining prey under deep snow conditions is so common a characteristic of the Great Gray Owl that plungemarks can be used to prove the presence of this species. ${ }^{1,5,6}$ Norberg, in a review of feeding behaviour of northern forest owls, pointed out that the large size of the Great Gray Owl's head and face "improves its probabilities of auditory detection of concealed prey and enhances localization accuracy. The asymmetry of the external ears improves sound localization.... Its large weight enables it to make deep plunge-holes in the snow and to catch prey deep below the snow surface where lighter owls could not possibly get at the prey." Norberg cites one report of a Great Gray Owl that plunged through a snow crust hard enough to bear an $80-\mathrm{kg}$ man. ${ }^{6}$

Typically, a perching or hovering owl - and the broad wings of the Great Gray owl suit it admirably for hovering or gliding slowly - locates prey by sound, then drops head downward and forcibly into the snow, breaking its fall with its wings and reaching deep with its long legs for its prey. Mikkola writes: "As it dives downward its head is suddenly directed towards its prey and it almost seems that the head hits the surface of the snow first. However, both Eero Kemila [whose photo beautifully illustrates this behaviour] and Leinonen ... believe that in the instant before hitting the snow the owl will draw back its head, extend its legs and stretch its feet forwards with the talons fully spread. However, the high speed of the dive renders it impossible to prove precisely what does happen by direct observation." ${ }^{4}$ Not all plunge-marks made by Great Gray Owls are of the same size; in some cases, birds drop only their feet into the snow, barely touching with their body. At times there may not even be any mark left by the wings. Small mammals feeding or tunnelling at or near the surface of the snow - and this is not uncommon - may be taken by a shallow pounce, rather than by a full-out dive. Thus interpretation of plungemarks requires some caution.

Brief mention has been made of an observation by Richard Knapton 


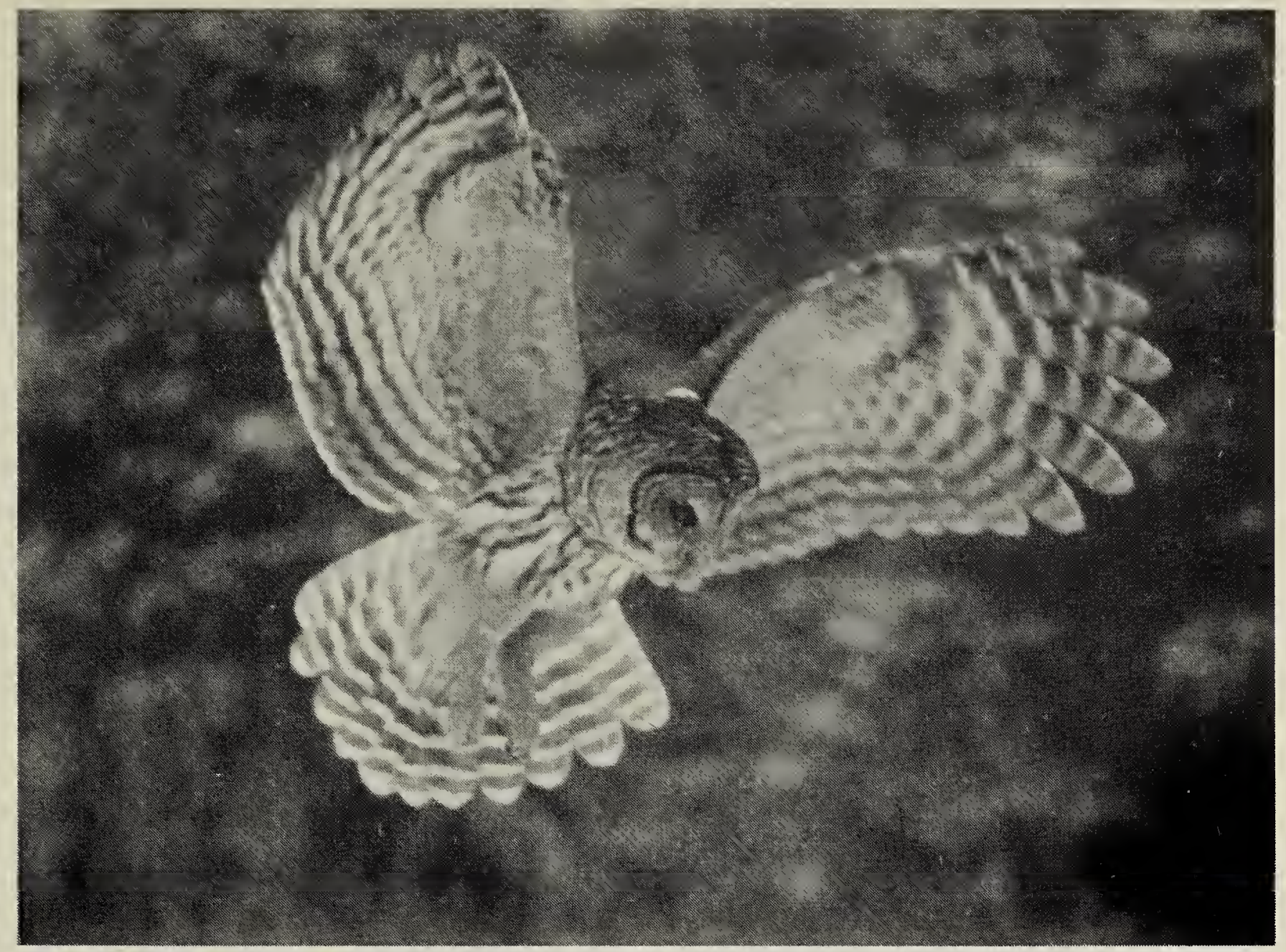

of snow-plunging by a Boreal Owl. ${ }^{5}$ Because of the apparent scarcity of this behaviour in this species, Knapton's note is presented here in detail for the first time. The following is from a letter he sent to Soren Bondrup-Nielsen on 25 January 1979: "A Boreal Owl has been seen in the Assiniboine 'Forest' here in Winnipeg for the past two days; today (25 January) I observed the bird for about 35 minutes at noon while it was hunting along ski trails and in open spots in the wood. On one occasion the bird plunged into the snow from a perch about 2 metres up in an aspen; the plunging behaviour seemed similar to that of the Great Gray Owls - that is, the bird finished its plunge into the snow with its wings open and resting on the surface of the snow (primaries were traced on the snow). The plunge hole was about $10 \mathrm{~cm}$ deep (estimated, not measured) and the shape resembled those of Great Grays large body indentation with 'bulges' on the side presumably caused by wings. It evidently failed to capture prey, as it flew onto a nearby perch with nothing in its talons. It continued hunting by flying distances up to 30 metres, perching and looking intently at the ground for up to 2 minutes, then off to another perch, and so on. The day was cloudy, totally overcast, hence the bird's activity at midday" (pers. corres., 26 October 1987, R. W. Knapton).

As Norberg indicated, the Boreal Owl may be too light in weight to successfully snow-plunge. Unless the snow is especially soft, it probably couldn't go deep and, moreover, its legs are relatively short compared to those of the Great Gray Owl. The Barred Owl, in the same genus as the Great Gray Owl, and considerably heavier than the little Boreal Owl, conceivably could snowplunge. Yet this behaviour is apparently uncommon in this species. Mark Elderkin, who studied Barred 
Owls in Nova Scotia, notes: "Although I have never actually witnessed this be- haviour, I have some evidence that it does occur and have seen plunge marks along woodedfield edges. Usually small bits of feathers betrayed the species of owl and in one instance, drops of blood indicated a successful capture. I would suggest that in severe winters when snows are deep and alternative foods are scarce, subnivean capture of small mammals are more frequent than in mild years. An eyewitness account of snow plunging conveyed to me by a local man confirmed the existence of the behaviour. In this instance, an unsexed Barred Owl was observed hunting along a wooded-field edge during daylight hours in 1985. Of three plunges made by this owl, only one was successful in the capture of an unidentified small mammal" (pers. corres., 6 September 1987).

Upon enquiry, Dave Johnson, who studies Barred Owls in north-central Minnesota, responded as follows: "Have never actually witnessed a Barred plunge, but have one observation from Jan. 1983, Becker County, MN, of a nice plunge hole made by a Barred. It was near one of my nest boxes, and I had seen a Barred in the vicinity on four occasions during that week. I have looked for Barred plunge holes for five years now. The plunge hole occurred in a small marsh pocket (30 yards across) in a northern hardwood forest type, where overhanging trees provided a perch. I recall snow depths of 15-18 inches in the marsh pocket" (pers. corres., 3 September 1987). The late Don Follen, a Wisconsin owl student, had this to say: "Snow plunging: I've seen Bd's [Barred's] on several occasions in the snow up to their pits. This is of course soft fluffy snow" (pers. corres., 24 August 1987).
Despite our many years in the field in winter in southeastern Manitoba looking for owls, Herb Copland and I have only three indications of snowplunging by Barred Owls. Late in the afternoon of 4 January 1981, along the Glen road east of East Braintree, we found fresh signs of snowplunging by a bird of Barred Owl size. There were at least six plungeholes in the snow over a grassy field. Except for the small size, they resemble marks made by Great Gray Owls. The holes were close to trees. Again, and in the same vicinity, on 11 January 1981 we saw similar plunge-holes in the afternoon, and then at 8:00 p.m. a Barred Owl came out and perched in a nearby tree. We assumed that it was the bird that had made several Barred Owl-size plunge-holes at a new site several kilometres away. At one plunge-hole there was an imprint of the owl's face showing the bill, just as we have seen at numerous Great Gray Owl plunge-holes. This imprint was the size of a Barred Owl's face.

In our experience, Barred Owls are seldom seen here, especially in winter. The species, as noted by Johnsgard, "is essentially a seminocturnal to nocturnal hunter."3 Apparently less bold and seemingly more restricted to hunting within woods than Great Gray Owls, only six Barred Owls have been seen by Herb Copland and myself over the past 20 winters. Jim and Patsy Duncan, on the other hand, recorded three sightings of Barred Owls in winter 1986-87: one at 5:00 p.m. - 12 December; one at 2:22 p.m. - 2 February; and one at 4:49 p.m. - 16 March. The latter bird, which they captured when it came into a lure, was reported as noticeably thin (pers. corres., 1987). Herb and I captured one at 3:15 p.m. on 4 February 1979, northeast of Lac du Bonnet. Upon seeing what we assumed 
to be a Great Gray Owl back some distance from the road in a grove of aspens, we set out to capture the bird; on the third cast of the lure, the owl came out from the trees in pursuit of it. We were surprised to see, when it was close, that it was a Barred Owl. It turned away at the last minute, but landed nearby and a moment later came in to a live mouse and was netted by Herb. Its belly plumage was wet and there was even a little ice on some parts. We guessed that it had roosted in wet snow in a tree cavity. It was kept in the car long enough to dry out its plumage before we released it.

I am particularly grateful to Richard W. Knapton for allowing me to use his observations of the Boreal Owl. Thanks for their information are also owing James R. Duncan, Patricia A. Duncan, Mark F. Elderkin, David $H$. Johnson and the late Donald G. Follen, Jr. For congenial companionship on owl forays, I am indebted to Herbert W. R. Copland.
1. COLLINS, K.M. 1980. Aspects of the biology of the Great Gray Owl. M.Sc. thesis, Univ. of Manitoba, Winnipeg. $219 \mathrm{pp}$.

2. CURRY-LINDAHL, K. 1978. Foreward In Clark, R.J., D.G. Smith, and L.H. Kelso. 1978. Working bibliography of owls of the world. NWF Scientific/Technical Series No. 1, National Wildlife Federation, Washington, D. C. 319 pp.

3. JOHNSGARD, P. A. 1988. North American owls, biology, and natural history. Smithsonian Institution Press, Washington, D. C. 295 pp.

4. MIKKOLA, H. 1983. Owls of Europe. Buteo Books, Vermillion, South Dakota. $397 \mathrm{pp}$.

5. NERO, R.W. 1980. The Great Gray Owl, phantom of the northern forest. Smithsonian Institution Press, Washington, D. C. 167 pp.

6. NORBERG, R.A. 1987. Evolution, structure and ecology of northern forest owls. In Nero, R.W., R.J. Clark, R.W. Knapton, and R.H. Hamre, eds. 1987. Biology and conservation of northern forest owls: symposium proceedings Gen. Tech. Rep. RM-142, Fort Collins, CO, USDA Forest Service, Rocky Mountain Forest \& Range Station. 309 pp.

"Recently, estimates on the number of species [of plants and animals] on earth have been revised dramatically upward, from around 5 or 10 million to between 30 and 50 million. The point is, no one knows. Only 1.4 million species have been classified." Verlyn Klinkenborg, Audubon Jan-Feb/92 